\title{
Evaluation of the Estral Cycle in Rats after Treatment with Dexamethasone for Polycystic Ovaries, Induced by Constant Illumination
}

\author{
Evaluación del Ciclo Estral en Ratones Después del Tratamiento con \\ Dexametasona para Ovarios Poliquísticos, Inducidos por Iluminación Continua \\ Heitor Arôxa Barros; Eleonora Figueredo de Moraes; Carina Scanoni Maia; \\ Álvaro Aguiar Coelho Teixeira \& ValériaWanderley Teixeira
}

BARROS, A, H.; MORAES, F. E.; MAIA, S. C.; TEIXEIRA, C. A. A. \& TEIXEIRA, W. V. Evaluation of the estral cycle in rats after treatment with dexamethasone for polycystic ovaries, induced by constant illumination. Int. J. Morphol., 24(3):509-514, 2006.

SUMMARY: The study aimed at obtaining basic information about estrous cycle in rats treated with dexamethasone, for polycystic ovaries, induced by constant illumination. It was used 30 female rats (Rattus norvegicus albinus) from the lineage Wistar, with 90 days years old, divided according the following groups: Group I - rats maintained in a light/dark cycle for 12/12 hours, and after 100 days submitted to the cyclicity evaluation (control); Group II - rats maintained under constant illumination during 100 days and after submitted to the cyclicity evaluation; Group III - rats maintained under constant illumination during 100 days and after treated with dexamethasone for five days, and, then, submitted to the cyclicity evaluation. The results showed that after 100 days of experiment, the animals from group I presented a normal cyclicity, being observed the four phases of the cycle. In the animals of groups II and III, it was observed a higher incidence in the estrous phase, with $85 \%$ and $76,5 \%$ respectively, characterizing the state of permanent estrous. It was observed the phase of diestrous with $15 \%$ in group II, and $23,5 \%$ in group III, not being observed the phases of proestrous and metaestrous. After treatment with dexamethasone, it was verified a great reduction in the estrous phases in the animals from group III, what was also observed in the animals from group II, reaching numbers of $34,5 \%$ and $20,85 \%$, respectively. Yet, there was an increase in the diestrous phase in group II $(64,57 \%)$, and group III (75\%). It has been noticed in these groups the presence of the proestrous phase with $0,92 \%$ in group II and 4,15\% in group III, not being observed the metaestrous phase. The treatment with dexamethasone during five days produces, more rapidly, a possible retake of the estrous cycle in rats with ovarian polycystic ovaries.

KEY WORDS: Estrous cycle; Polycystic ovaries; Dexamethasone; Rats.

\section{INTRODUCTION}

Rodents are animals from the polyestrous type, i. e., they present five regular and successive estrous cycles, which are manifested through morphological changes in the ovaries, uterus, vagina and mammal glands. (Long \& Evans, 1922; Astwood, 1939; Griffith \& Farris, 1942; Mandl, 1951; Bertalanffy \& Lau, 1963; Mozanska, 1972; Simões, 1979, 1984).

The literature reports that several factors can lead to the interruption of the estrous cycle and, because of this, the permanent estrous in rats is induced. Among these factors, constant illumination, sound, steroid hormones use in newly born, ionizing radiation exposition and pinealectomy are highlighted. (Pfeiffer, 1936; Everett, 1939; Barraclough \& Leathem, 1954; Martins et al., 1962; Singh, 1969; Wrenn et al., 1969; Aihara et al., 1988; Pardi, 1992; Patriarca, 1995; Santos et al., 1995).

The state of permanent estrous and, consequently, the loss of cyclic character of sexual activity constitute one of the most interesting phenomena in the endocrinology of reproduction (Rodrigues Lima, 1966). Due to this fact, it is observed an increase in the production of androgens and estrogens in the ovaries of rats (Chiórboli, 1970).

It is known that constant illumination inhibits the synthesis of melatonin through the pineal gland, in which it is produced in the environmental darkness phase, as there is a diurnal harmony in the liberation of melatonin (Buckle, 1983; Neves, 2000). 
When rats are exposed to a continuous luminous stimulus, or pinealectomized, they enter a state of permanent estrous and develop polycystic ovaries (Singh; Prata Lima et al., 1995).

Studies have shown that the glycocorticoid hormones inhibit growth in a general way and its effects can be observed in the reproductive functions. Several authors report that the glycocorticoid, among them the dexamethasone, inhibit the number of induced answers by the estrogens, including the blocking of myotic activity (Szego \& Roberts, 1953; Szego \& Davis, 1969; Campbell, 1978; Markaverich et al., 1981; Stewart et al., 1983; Bigsby \& Cunha, 1988).

According to Queiroz (2004), rats with polycystic ovaries treated during five and ten days and then euthanasiated present a reduction in the amount of ovarian cysts, though without the formation of luteal bodies. However, by administering dexamethasone for a period of 15 days, it was verified a reversion in the polycystic ovaries due to the presence of great amounts of luteal bodies, indicating, thus, a possible retaken of the ovarian cycle. So, before the exposed, the present study aimed at obtaining basic information about the estrous cycle in rats treated with dexamethasone.

\section{MATERIAL AND METHOD}

It was used 30 albino rats (Rattus norvegicus albinus), 90 days old, virgin, weighing nearly $200 \mathrm{~g}$, from the Wistar lineage, from the vivarium of the Department of Morphology and Animal Physiology from Universidade Federal Rural de Pernambuco. The animals were confined in cages and maintained under food and water ad libitum, temperature of $22^{\circ} \mathrm{C}$ and artificial lightning using fluorescent lamps (brand name Phillips, daylight model, 40W), which established the photoperiod of 12 hours light and 12 hours dark, considering the period with light from 6 a.m. to 6 p.m. After a period of adaptation, vaginal smears were collected for the determination of the estral cycle. The animals that presented three regular estrous cycles were divided randomly in three groups, each of them constituted by 10 animals:

Group I - rats maintained in light/dark cycle (12/12 hours), and after 100 days submitted to the evaluation of cyclicity (control); Group II - rats maintained under constant illumination during 100 days, and then submitted to the evaluation of cyclicity; Group III - rats maintained under constant illumination during 100 days, and then treated with dexamethasone for five days and submitted to the evaluation of cyclicity.

For the constant luminous stimulus, it was used a box of wood measuring nearly $0,5 \mathrm{~m}^{3}$, appropriately dimensioned and ventilated, containing two lamps (Phillips, daylight model, $20 \mathrm{~W}$ each) which provided 400 Lux in the place occupied by the animals. After 100 days of the experiment, colpocytological exams were done in group I, for the confirmation of cyclicity, and in groups II and III for the confirmation of permanent estrous. After the treatment with dexamethasone, all groups were submitted to exams. The treatment with dexamethasone was done using dexamethasone dissodic phosphate (Decadron $(\circledR)$ ), in a concentration of $4 \mathrm{mg} /$ $\mathrm{ml}$, in which it was administered by means of intraperitoneal injections in a dosage of $0,2 \mathrm{ml} /$ day/animal, according to the methodology described by Cruz et al. (1996).

Fig. 1. Frequency of the estrous cycle in the animals from experimental groups after 100 days.

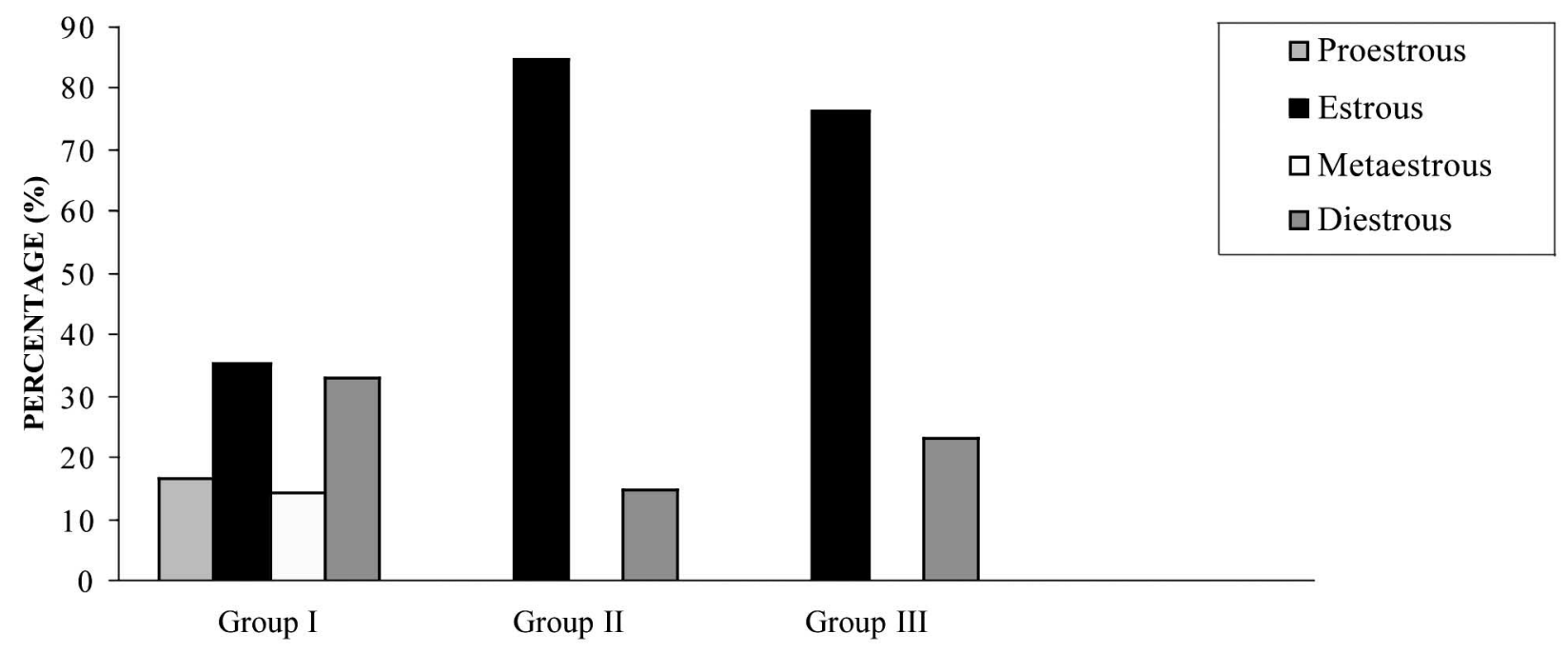




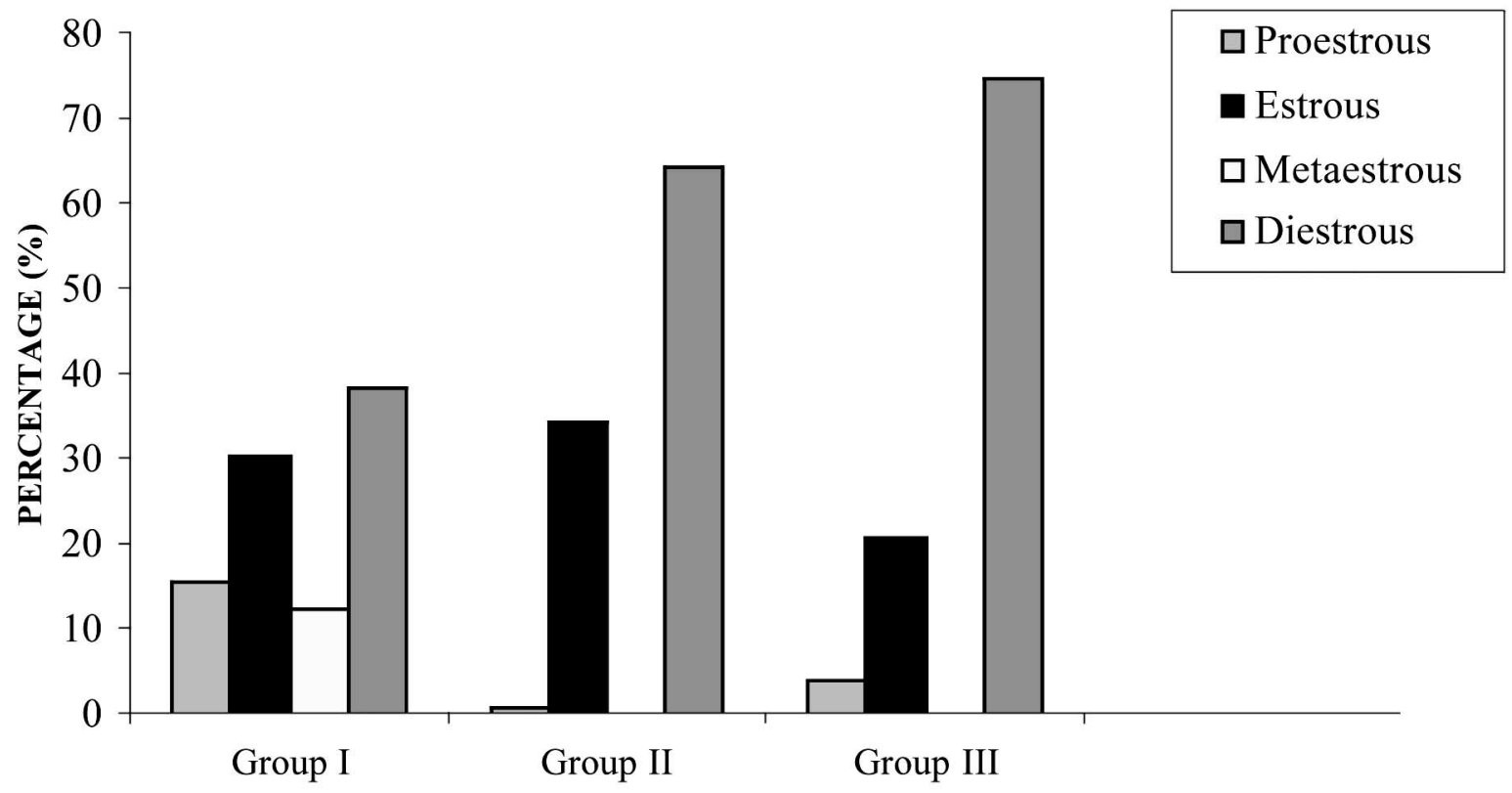

\section{RESULTS}

The colpocytological exams showed that the animals from group I presented a normal cyclicity, being observed the four phases of the cycle. Yet, in the animals from groups II and III, it was observed a higher incidence in the estrous phase with a percentage of $85,00 \%$ and $76,50 \%$, respectively, characterizing the state of permanent estrous. Also, it was observed in these groups the diestrous phase with a percentage of $15,00 \%$ in group I, and $23,50 \%$ in group III, not being observed the proestrous and metaestrous phases (Fig. 1.).

The colpocytologic exams after the treatment with dexamethasone showed that the animals from group I also presented a normal cyclicity, being observed the four phases of the cycle. However, the animals from groups II and III were observed as having a stressed incidence in the estrous phase, with a percentage of $34,50 \%$ and $20,85 \%$, respectively, and the increase of the diestrous phase with $64,58 \%$ for group II, and 75,00\% in group III. It was also noticed the presence of the proestrous phase with a percentage of $0,92 \%$ in group II and 4,15\% in group III, not being observed the metaestrous phase (Fig. 2.).

\section{DISCUSSION}

The constant illumination promotes reduction in the levels of melatonin hormones, and elevates the levels of circulating estrogens causing, consequently, the permanent estrous phase. The analysis of the estrous cycle in the animals of groups II and III after 100 days of the experiment showed a higher incidence in the phase of the estrous, reaching more than $70 \%$ of the cycle, characterizing the disruption of cyclicity. These results are according to the ones obtained by Singh, Santos et al. and Queiroz.

Regarded to the reduction of the estrous phase and increase of the diestrous phase, besides the appearance of the proestrous phase in the animals of group II, observed in graphic 2, this can be related to the retaken of the nocturne release of melatonin in these animals, because, according to Johnson et al. (1982), its levels vary according to the different estrous cycle phase of rats, being higher during the metaestrous and diestrous. Besides, the highest incidence of estrous in rodents, produced by constant illumination, can be reverted by transference for shorter photoperiods or by the administration of melatonin (Gittes \& Chu, 1965; Teixeira et al., 2002). However, it must be 
mentioned that in group III (treated with dexamethasone) the reduction in the estrous phase, as well as the increase of the diestrous and proestrous phases was more stressed if compared to group II, indicating a possible retaken of the estrous cycle. This fact must be related to the stimulating action of the dexamethasone over the release of melatonin, as, according to Luboshitzky, et al., (2000) and Barriga et al. (2002), it has been observed that rats pinealectomized and treated with melatonin, right after or in the end of a 3 months period, the estrous cycle was regular, indicating a regulatory activity of melatonin in the maintenance of the estrous cycle. This way, the dexamethasone can have exerted an indirect effect to quicken the return of the estrous cycle in these animals.

BARROS, A, H.; MORAES, F. E.; MAIA, S. C.; TEIXEIRA, C. A. A. \& TEIXEIRA, W. V. Evaluación del ciclo estral en ratones después del tratamiento con dexametasona para ovarios poliquísticos, inducidos por iluminación continua. Int. J. Morphol., 24(3):509$514,2006$.

RESUMEN: El objetivo del estudio fue obtener información básica del ciclo estral en ratones tratados con dexametasona, en ovarios poliquísticos, inducidos por iluminación continua. Fueron utilizados 30 ratones albinos (Rattus norvegius albinus) del linaje Wistar, con 90 días de edad, divididos en los siguientes grupos: Grupo I - ratones mantenidos en ciclo claro/oscuro de 12/12 horas, tras 100 días sometidos a la evaluación de la ciclicidad (control). Grupo II - ratones mantenidos bajo iluminación continua, durante 100 días y luego sometidos a la evaluación de la ciclicidad. Grupo III - ratones mantenidos bajo iluminación continua, durante 100 días, después tratados con dexametasona durante cinco días y sometidos a la evaluación de la ciclicidad. Los resultados mostraron que tras 100 días de pruebas, los animales del grupo I presentaron una ciclicidad normal, siendo observadas las cuatro fases de éste. En los animales de los grupos II y III se verificó una mayor incidencia de fase de estro, con el porcentaje de $85 \%$ y 76,50\%, respectivamente, caracterizando el estado de estro permanente. Fue observada la fase de diestro en el 15\%, en el grupo II, y 23,5\% en el grupo III, no siendo observadas las fases de proestro y metaestro. Posterior al tratamiento con dexametasona, se verificó una reducción acentuada en la fase de estro en los animales del grupo III, lo que también fue observado en los animales del grupo II , alcanzando un 34,5\% y 20,85, respectivamente. Hubo incluso aumento de la fase de diestro en el grupo II (64,58\%), y grupo III (75\%). Notamos en esos grupos, la presencia de la fase de proestro en el $0,92 \%$ en el grupo II y $4,15 \%$ en el grupo III, no siendo observada la fase de metaestro. El tratamiento con dexametasona durante cinco días, produce más rápidamente una eventual vuelta del ciclo estral en ratones con poliquistosis ovárica.

PALABRAS ClAVE: Ciclo Estral; Ovarios Poliquísticos; Dexametasona; Ratones.

\section{REFERENCES}

Aihara, M.; Kobayashi, H.; Kimura, T.; Hayashi, S. \& Kato, J. Changes in uterine estrogen receptor concentration in persistent estrus and persistent diestrous rats. Endocrinology Japanese, 35(1):57-70, 1988.

Astwood, E. B. Changes in the weight and water content of the uterus of normal rat. Am. J. Physiology, 126:162-70, 1939.

Barraclough, C. A. \& Leathem, J. H. Infertility induced in mice by a single injection of testosterone propionate. Proc. Soc. Exptl. Biol. Med., 85:673-4, 1954.

Barriga, C.; Marchena, J. M.; Lea, R. W.; Harvey, S. \& Rodríguez, A. B. Effect of stress and dexamethasone treatment on circadian rhythms of melatonin and corticosterone in ring dove (Streptopelia risoria). Mol Cell Biochem., 232(1-2):27-31, 2002.

Bertalanffy, F. D. \& Lau, C. Mitotic rates, renewal times, and cytodynamics of the female genital tract epithelia in the rat. Acta Anat., 54:39-81, 1963.
Bigsby, R. M. \& Cunha, G. R. Progesterone and dexamethasone inhibition of uterine epithelial proliferation in models of estrogen - independent growth. Am. J. Obstetric and Gynecology, 158:646-50, 1988.

Buckle, J. W. Animal Hormone. London, Edward Arnold, 1983. pp. 20-36.

Campbell, P. S. The mechanism of the inhibition of uterotropic responses by acute dexamethasone pretreatment. Endocrinology, 103:716-23, 1978.

Chiórboli, E. Contribuição ao estudo da produção in vitro de hormônios esteróides, pelo ovário das ratas normais e precocemente tratadas com testosterona. São Paulo, 1970. [Tese de Doutorado - Escola Paulista de Medicina].

Cruz, F. C. M.; Smaniotto, S. \& Simões, M. J. Morphological aspects of the cervical mucosaof persistent estrous rats under action of estrogen and/or dexamethasone. Braz. J. Morphol. Sciences, 13(1):100, 1996. 
Everett, J. W. Spontaneous persistent estrus in a strain of albino rats. Endocrinology, 25:123, 1939.

Gittes, R. F. \& Chu, E. W. Reversal of the effect of pinealectomy in female rats by multiple isogeneic pineal transplants. Endocrinology, 77:1061-7, 1965.

Griffth Jr., J. Q. \& Farris, E. J. The rat in laboratory investigation. Philadelphia, Lippencott Company, 1942.

Johnson, L. Y.; Vaughan, M. K.; Richardson, B. A.; Petterborg, L. J. \& Reiter, R. J. Variation in pineal melatonin content during the estrous cycle of the rat. Proc. Soc. Exper. Biol. Med., 169:416-9, 1982.

Long, J. \& Evans, H. M. The estrus cycle in the rat and it's associated phenomena. Memory University, 6:1-148, 1922.

Luboshitzky, R.; Qupti, G.; Shen-Orr, Z. \& Hardoff, R. Decreased melatonin secretion in a phenotypically male 46,XX patient with classic 21-hydroxylase deficiency. Exp. Clin. Endocrinol. Diabetes, 108(3):237-40, 2000.

Mandl, A. M. The phases of oestrus cycle and adult white rat. J. Experience Biological, 28:576-84, 1951.

Markaverich, B.; Upchurch, S. \& Clark, J. H. Progesterone and dexamethasone antagonism of uterine growth: a role for a second nuclear binding site for estradiol in estrogen action. J. Steroid Biochemistry, 14:125-32, 1981.

Martins, T.; Ladosky, W.; Velloso, L. F. Masculinização do tipo cronológico da atividade do ovário por efeito central da testosterona injetada em recém-natos. Anais da Academia Brasileira de Ciências, 34:26, 1962.

Mozanska, T. Histological and histochemical studies on the uterus and vagina in the course of the estrous cycle in female white rats. Ann. Med. Sect. Pol. Acad. Sci., 17: 75-131, 1972.

Neves, W. S. Cronobiologia e suas aplicações na prática médica. 7(1): 2000. Disponível em: <http:// www.famerp.br/publicacoes/revistahb/Vol7-N1/5cronobiologia.html>. Acesso em: 20 de Maio de 2004.

Pardi, P. C. Aspectos morfológicos do endométrio de ratas albinas em estro permanente. São Paulo, 1992. [Tese de Mestrado - Escola Paulista de Medicina].
Patriarca, M. T. Efeitos do tamoxifeno no endométrio de ratas em estro permanente. São Paulo, 1995. [Tese de Mestrado - Escola Paulista de Medicina].

Pfeiffer, C. A. Sexual differences of hipophyses and their determination by gonads. Am. J. Anat., 58:195, 1936.

Prata Lima, M. F.; Soares Jr; J. M.; Reis, J. C.; Salum, R. \& Baracat, E. C. Desenvolvimento de policistose ovariana em ratas pinealectomizadas. Reprodução $e$ Climatério, 10(2):73-5, 1995.

Queiroz, C. B. Ação da dexametasona sobre ovários policísticos e endométrio, de ratas em estro permanente. Recife, 2004. [Monografia apresentada para obtenção do Título de Bacharel em Ciências Biológicas - Universidade Federal Rural de Pernambuco] 37p.

Rodrigues Lima, G. Contribuição para o estudo da fisiopatologia de ratos em estro permanente Sensibilidade uterina a ocitocina. São Paulo, 1966. [Tese de Doutorado - Escola Paulista de Medicina].

Santos, J. M.; Smaniotto, S.; Evêncio-Neto, J. \& Simões, M. J. Aspectos morfológicos do endométrio de ratas submetidas à iluminação constante (estro permanente). Arquivos do Instituto Biológico, 62(supl):47, 1995.

Simões, M. J. Aspectos morfológicos do endométrio de ratas da colônia $2 B A W$, nas subfases inicial, intermediária e final do estro e diestro. São Paulo, 1979. [Tese de Mestrado - Escola Paulista de Medicina].

Simões, M. J. Aspectos morfológicos e morfométricos do endométrio de ratas albinas nas subfases inicial, intermediária e final do proestro e metaestro. São Paulo, 1984. [Tese de Mestrado - Escola Paulista de Medicina].

Singh, K. B. Persistent estrus: An experimental model of the policystic ovaries. Obstet. Ginec. Survey., 104:1008-11, 1969.

Stewart, P. J.; Zaloudek, C. J.; Murphy Inman, M. \& Webster, R. A. Effects of dexamethasone and indomethacin on estrogen-induced uterine growth. Life of Science, 33: 2349-56, 1983.

Szego, C. M. \& Roberts, S. Steroid action and interaction in uterine metabolism. Rec. Prog. Horm. Res., 8: 41969, 1953. 
Szego, C. M. \& Davis, J. S. Inhibition of estrogen induced cyclic AMP elevation in rat uterus. II: By glucocorticoids. Life of Science, 8:1109-16, 1969.

Teixeira, A. A. C.; Simöes, M. J.; Evêncio Neto, J. \& Wanderley-Teixeira, V. Morphologic aspects of the endometrium, in the estrus phase, of pinealectomized rats. Int. J. Morphol., 20(2):145-9, 2002.

Wrenn, T. R.; Wood, J. R. \& Bitman, J. Oestrogen responses of rats neonatally sterilized with steroids. $J$. Endocrinology, 45:415-20, 1969.
Correspondence to:

Prof. Dra. Valeria Wanderley Teixeira.

Universidade Federal Rural de Pernambuco.

Departamento de Morfologia e Fisiologia Animal.

Área de Histologia

Rua Dom Manoel de Medeiros $s / n$ - Dois Irmãos

CEP: 52.171-900

Recife-PE

BRASIL

Email:valeria@ufrpe.br

Received : 19-05-2006

Accepted: 16-08-2006 